\title{
Federalism, Territorial Autonomy and the Management of Ethnic Diversity in Africa: Reading the Balance Sheet
}

\author{
Yonatan Tesfaye Fessha
}

LLB (Addis Ababa University), LLM (Pretoria), Ph.D. (Western Cape). Senior lecturer, Faculty of Law, University of the Western Cape; Research Fellow, Community Law Centre.

\section{Introduction}

Africa most likely accounts for a lion's share of defunct federations. In the wake of independence from colonial powers, and possibly driven by the euphoria of Pan-Africanism, a number of independent states in Africa established federations with their neighbours. In 1959, Senegal and Sudan (present day Mali), two former-French colonies, joined to create the Mali Federation. The federations of Rhodesian (including what are now Zambia and Malawi) and Nyasaland (what is now known as Malawi) was established in 1953. Libya and Egypt joined Syria to establish the Federation of Arab Republics in 1972. Eritrea joined Ethiopia in a United Nations' sponsored federation in 1952. The Federal Republic of Cameroon was established in 1961, bringing together French and British Cameroon, which used to be under a single German colonial administration before the First World War.

As the opening sentence of this article suggests, the history of federalism in Africa is not encouraging. Federalism in Africa was, to put it mildly, an ill-fated experiment. The Mali Federation collapsed before its second anniversary. The Federation of Arab Republics was barely into its fifth year when it was abolished in 1977. The Federation of Rhodesian lasted from 1953-1963. The story of other federations on the continent is no different. As Osaghae notes, "federalism has 
failed to thrive and take firm roots in Africa and, on balance, does not appear to have dramatic positive effects in countries that have tried the federal solution".

Recent developments indicate that the federal idea that was never given a chance to develop and was 'being strangled at birth' is now re-entering the political and constitutional scene of several African countries. This short article aims at providing a preliminary balance sheet of the records of federalism from one particular angle, namely the management of ethnic diversity. It examines how African federations have responded to the ethnic diversity that characterizes their societies. In particular, it looks at how the territorial autonomy solution provided by these federations has helped to manage fault lines.

The article commences with the discussion of the brief historical narration of African federations and their attempts to deal with the anxieties of ethnic groups that were concerned about their status in post-colonial Africa. It then analyses the nature of politicized ethnicity in Africa and its demands on the (re)structuring of the state. The focus then shifts to the current federations that, in one way or another, deal with the management of ethnic diversity and examines how the territorial autonomy solution, implicit in these federations, have helped to deal with the challenges of ethnic diversity.

\section{Federalism and ethnic diversity in post-colonial Africa: Detour through history}

Not all federations established in Africa had as their objective the accommodation of ethnic diversity. Federations were established for many reasons. In fact, some of the federations that were established in the early days of post-colonial Africa were simply the creations of colonial powers or their extensions. The Federation of Rhodesian was partly established to perpetuate white hegemony. As King (47) notes "[t]he character of the new federation of Rhodesian and Nyasaland was determined by the presence of (at their peak) three thousand white settlers, over three quarters of whom were in Southern Rhodesian, who ruled over seven million black Africans." Similarly, some of the federations in Africa were created as the result of the decision of colonial powers to use federalism as "a formula for the unification of territorial units of separate antecedents." 3 A prime example is Nigeria, which was established as a result of the decision to bring together, in 1914, "the

1. Eghosa Osaghae, "Federalism and the management of diversity in Africa," in: Identity, culture and politics, vol. 5 Nos. $1 \& 2$ (2004): 162-178, 171.

2. Tony King, "Partnership and paternalism: The federation of Rhodesian and Nyasaland (1953-1963)," in: Defunct federalisms: Critical perspectives on federal failure, eds. Kavalski, Emilian and Zolkos Magdalena (Hampshire: Ashgate, 2008), 47-59.

3. Crawford Young, "Ethnic diversity and public policy: An overview," in Ethnic diversity and public policy: A comparative enquiry, ed. Young Crawford (Basingstoke and London: Macmillan Press, in association with UNRISD, 1998), 10. 
two contiguous British protectorates of Northern and Southern Nigeria". Eventually this led to the establishment of a three-region federal system in $1954 .{ }^{4}$ In other cases, the decision to federate was mainly motivated by the desire to benefit from a large state. Administrative convenience and efficiency were also some of the reasons behind the establishment of federations.

Yet, a number of federations or semi-federations in Africa were designed to respond to the multi-ethnic reality that characterizes many of these post-colonial states. The option of centralized versus decentralized states dominated the political discourse of African states beginning from the early days of independence. At the centre of this debate was the tension between the management of ethnic diversity and the promotion of national unity. Political leaders considered a strong centralized state essential for the purpose of forging national unity. This was considered by many African governments to be their most pressing task, to effectively govern the newly born states. They, as a result, turned a blind eye to the challenges associated with ethnic diversity. Building the nation was their main agenda. "In the heydays of independence, that began in Ghana in 1957", notes Welsh, "accelerating in the 1960s 'nation building' was assumed to be the priority of all the newly emerging [African] states". 5 This was also clear from the public statement of the founding fathers of many of these African states:

Zambia's President Kaunda said that 'our aim has been to create genius nations from the sprawling artifacts the colonialist carved out'. Cameroons' President Abidjo sees the institution of the state as a means to achieve nationhood. For him, L'intégration nationale c'est l'adaptation des citoyens aux différentes structures d'État'. The same is true of Senghor who writes, 'The state is...primarily a means to achieve the nation'.

At the centre of the nation-building project is the attempt to achieve a homogenized society. This was so aptly stated by Deng who noted that "[u]nity was postulated in a way that assumes a mythical homogeneity amidst diversity." The declaration of the post-colonial states as 'indivisible and unitary' is the major feature of many of the independence constitutions of African states.

This attempt at forging a national identity amidst huge diversity was carried out in the face of countervailing concern among some ethnic groups who desired a system that provides them with some space to manage their own affairs without being vetoed by the dominant group. They were concerned about their political

4. Rotimi Suberu, "Attractions and contradictions of ethnic federalism: The Nigerian experience," in Ethnic federalism: The Ethiopian experience in a comparative perspective, ed. David Turton (Athens: Ohio University Press, 2006), 65-89.

5. David Welsh, "Ethnicity in sub-saharan Africa," in: International Affairs 72 (1996): 477-491, 477.

6. Benyamin Neuberger, "State and nation in African thought," in: Nationalism, ed. John Hutchinson and Anthony Smith (Oxford: Oxford University Press, 1994), 233-234, 235.

7. Francis M. Deng “Ethnicity: An African predicament,” The Bookings Review 15 (3) (1997): 28-31. 
status in the newly born states and feared or perceived domination by numerically dominant groups. As a result, they demanded a system that devolves power and allows communities to exercise control over their own affairs without interference from the dominant group. In Kenya, for example, the small ethnic groups feared domination by the Kikyu-Luo alliance, the two largest ethnic groups in Kenya. ${ }^{8}$ Organized under the umbrella of the Kenya African Democratic Party (KADU), one of the two major political parties in independent Kenya, they called for a "Majimbo Constitution", the Kenyan term for a federalist constitution. They pressed for a federal system of government to avoid what they perceived as Kikuyu dominance. Similarly, one of the issues that confronted Uganda was the status of the Buganda ethnic group, who, based on their proud imperial history related to the Baganda Kingdom, demanded for federo, the term Ugandans use to refer to subnational autonomy based on the principle of federalism. ${ }^{9}$ The situation was similar in the DRC, where the federalists insisted on a constitution that provided for provincial autonomy. ${ }^{10}$

Eventually, the debate was resolved predominantly in favour of those that championed a centralized unitary state. But this was not without concessions that saw the inclusion of the federal idea in some of the independence constitutions. Kenya's first constitution was imbued with strong elements of 'Majimbo'. The country was divided into eight autonomous provinces each with their own parliaments that exercise constitutionally assigned powers and functions. ${ }^{11}$ The independence constitution of the war-torn Democratic Republic of Congo was explicitly federalist. It declared that the Republic "is composed of the city of Leopoldville and the autonomous provinces." 12 The autonomy of the provinces was explicitly guaranteed by the Constitution. Another country that adopted an independent constitution with federal features was Uganda. The federal states were established to accommodate the Buganda ethnic group. Under the independence constitution, Buganda enjoyed a special status while most of the rest of Uganda

8. Yash Ghai, "Devolution: Restructuring the Kenyan state," in: Journal of Eastern African Studies, 2:2 (2008): 211-226.

9. Osaghae, "Federalism and the management of diversity in Africa,"

10. Jeremy Sarkin, 2001 "Towards finding a solution for the problems created by the politics of identity in the Democratic Republic of the Congo (DRC): Designing a constitutional framework for peaceful cooperation" in: Solomon, Hussein (ed.) "Politics of identity and exclusion in Africa: From violent confrontation to peaceful cooperation" available at http://www.kas.de/db_files/dokumente/7_dokument_dok_pdf_5094_2.pdf (67-81) (accessed on 15 February 2012)

11. H. W. O. Okoth-Ogendo, "Constitutions without constitutionalism: Reflections on an African political paradox," in Constitutionalism and democracy: Transitions in the contemporary world, ed. D. Greenberg et al (New York, OUP, 1993), 65.

12. Article 4 Constitution of the Congo (Leopoldville) of 30 May 1960.

L'Europe en formation no363 Printemps 2012 - Spring 2012 
was governed by the central government under a unitary arrangement. ${ }^{13}$ Buganda was allowed to retain the monarchy. It was administered by a directly elected parliament and prime minister. It also maintained its own school system and own police force. ${ }^{14}$ Similarly, the Nigerian federation that was established following the amalgamation of colonial areas also adapted to responses to the challenges of ethnic diversity. ${ }^{15}$

As indicated earlier, these important concessions to the federal idea were, with the singular exception of Nigeria, short-lived. The move towards a centralized unitary state did not take long. In Kenya, it was only after one year into the new constitution that a decision was made to transform Kenya into a unitary state. The government refused to implement 'devolution to provinces'; "[e]lections were never held and the provinces were reduced to administrative structure" within a centralized state. ${ }^{16}$ Similarly, barely five years passed when the national government of Uganda introduced a new constitution that brought an end to the special status of Buganda, transforming Uganda into a complete unitary state. Across the continent, a political claim based on ethnic identity was particularly regarded as an 'enterprise' that poses a threat to the fragile nation that the colonial powers left behind; it was regarded as a recipe for state disintegration. Many went to the extent of outlawing or preventing the organization of political parties along ethnic lines.

As the detour through the history of federalism in Africa reveals, there was considerable clamour for a variant of federal arrangement that would help to preserve historical distinctiveness and protect small groups from the hegemony of large ethnic groups. As a result, important elements of federalism and subnational autonomy found their way into the independence constitution of several countries. However, the political commitment to these constitutional promises was glaringly absent. The clear consequence was the strangulation of federalism at birth in several African states. Large centralized states became the preferred mode of governance.

\section{Politicized ethnicity and its implications on the restructuring of the state in Africa}

However, a half-century of the centralization of power in African countries has not delivered political stability. In fact, it has provoked violent responses from

13. Joel Barkan, "Ethnic fractionalization and the propensity for conflict in Uganda, Kenya and Tanzania," in On the fault line: Managing tensions and divisions within societies, eds. Greg Herbst, Jeffrey, McNamee, Terence and Mills (Profile books: London, 2012), 150-169, 157.

14. Barkan, "Ethnic fractionalization and the propensity for conflict in Uganda, Kenya and Tanzania," 156.

15. Suberu, "Attractions and contradictions of ethnic federalism: The Nigerian experience,"

16. Brakan, "Ethnic fractionalization and the propensity for conflict in Uganda, Kenya and Tanzania," 162.

L'Europe en formation $n^{\circ} 363$ Printemps 2012 - Spring 2012 
different political movements and groups. The proliferation of ethnic based liberation movements in many African states is often attributed to the coerced nation building project that employed a highly centralized state as its primary vehicle. But the failure of the central government to deliver political stability has not necessarily generated plenteous demand for federalism or subnational autonomy in one form or the other. Although ethnicity has and continues to play an important role in political mobilization in most African states, subnational autonomy is not necessarily the agenda of many of the political formations on the continent. This is partly because of the particular role that ethnicity has assumed in post-colonial Africa, which, to a large extent, dictated the nature of ethnic based claims that characterized African states. This is about the nature of nation-building projects with which most African states have been preoccupied with for the last half-acentury and the implication it holds for political mobilization. ${ }^{17}$

At one end of the spectrum are African countries that tried to build a nation through the development of common language, culture and history by attempting to diffuse the language and culture of the majority or dominant group. In Sudan, the decision to develop the identity of the state along the language and culture of the northern Muslim Arab Sudanese and impose that culture on the largely black and Christian South is a prototype of such form of nation-building. ${ }^{18}$ The effort to build a nation in Ethiopia was largely characterized by the attempt to diffuse the language, culture and history of the Amhara over the rest of the population. ${ }^{19}$ In Malawi, the attempt at building a common national identity was based on the elevation of the Chewa as the embodiment of the 'national culture' (an ethnic group whose language was considered the sole national language). The Chewa culture was regarded as "the cornerstone of nationhood and source of its political iconography". ${ }^{20}$ Similarly, the development of a nation modelled on the language and culture of the Tswana was the hallmark of the nation-building project that Botswana pursued. Based on the motto that "we are all Tswana", the government sought to build a nation by diffusing the language and culture of Tswana on the rest of the population. As Werbner notes, the policy "left virtually

17. For a detailed discussion, see Will Kymlicka, "National-building and minority rights: Comparing Africa and the West," in Ethnicity and democracy in Africaeds. Bruce Berman, Dickson Eyoh and Will Kymlicka (Athens: Ohio University Press, 2004), 54-72.

18. Anna Rader, "Overcoming the past: War and peace in Sudan and south Sudan," in multi-case review of the world's most potent faultlines, eds. Herbst, Jeffrey, McNamee, Terence and Mills, Greg (2012), 45-68.

19. Yonatan Fessha, Ethnic diversity and federalism: Constitution making in South Africa and Ethiopia (Surrey: Ashgate. 2010).

20. D. Kaspin, "Tribes, regions, and nationalism in democratic Malawi," in Ethnicity and group rights, eds. Shapiro, Ian and Kymlicka, Will (New York and London: New York University Press, 1997), 464-503, 483. 
no space in the public sphere for the country's many non-Tswana cultures, unless recast in a Tswana image" ${ }^{21}$

Other African states, however, pursued the same objective of building a nation-state but based on non-ethnic premises. They sought to build a common national identity not by attempting to homogenize their population along the language and culture of a particular ethnic group but by appealing to non-ethnic bases for identification with the state. Based on their motto 'kill the tribe to build the nation' (Frente da Libertação de Moçambique, Frelimo), they declared a commitment to build a "common national identity,... developing common public institutions and a common public sphere operating in a common language", ${ }^{22}$ which was the culturally neutral colonial language (i.e. English, French or Portuguese). The end result was not substantially different.

Although the language and culture of a particular ethnic group was not used as a vehicle to develop a common national identity, the nation-building project in many of these African states did not succeed in developing a common national identity on a supra-ethnic basis. Many of these African states often ended up creating a state in which a particular group enjoyed a privileged position vis à vis the rest. The policy of successive regimes using state resources to advantage members of their ethnic group meant that "access to state power is ethnified". ${ }^{23}$ In Kenya, the hegemony of the Kikuyu was established under Jomo Kenyatta, the first president of independent Kenya. When Daniel Arap Moi became president, it was Kalenjin's 'time to eat.' Moi ensured that the key cabinet, the civil service and the army positions were controlled by Kalenjins, particularly marginalizing the Kikuyus. The ethnification of the state continued with the return of the Kikuyu hegemony when Kenya embarked on a multiparty system while Mwai Kibaki, a Kikyuyu, became President. ${ }^{24}$ The dominance of the Chewa in Banda Hasting's 30 year rule of Malawi, the Muslim Arabs in Sudan, the Hutus and the Tutsi in the pre-1994 Rwanda and Burundi respectively is well documented. The political history of most African states is drawn from the same book. ${ }^{25}$

Although both attempts at building a nation have been less than successful and ended up creating a state which is identified with a particular ethnic group, the grievances they created and the political movements that ensued are not nec-

21. R. Werbner, "Introduction: Challenging minorities, difference and tribal citizenship in Botswana" in Journal of Southern African studies, 28(4) (2002): 676.

22. Kymlicka, "National-building and minority rights: Comparing Africa and the West,"

23. Ibid.

24. For more on ethnicity and Kenya see: Barkan, "Ethnic fractionalization and the propensity for conflict in Uganda, Kenya and Tanzania,"

25. The clearest exception might be Tanzania where, in so far as mainland Tanzania is concerned, ethnicity has not emerged as a major political divide. As a result, access to state power is not 'ethnified' and political mobilization does not follow ethnic lines. 
essarily the same. Ethnic groups that are threatened by the first form of nation building have engaged in ethnic-based nationalist movements that sought to reverse the policy of population homogenization. At the centre of their struggle is a claim for the recognition of their language and culture and an attempt to redefine the identity of the state. In their effort to advance their version of nationalism (i.e. minority nationalism) and thereby counter the state-led hegemonic nationalism, they sought not only a subnational unit in which they are in the majority but also a subnational unit that has the power to exercise control over its own resources and identity-related matters like language, culture and education. Exercising control over language policy, curriculum in schools and maintaining monopolies over broadcasting agencies "[has] been crucial to nation-building strategies" ${ }^{26}$ In short, the claim for subnational autonomy is at the centre of their political contestations.

That is not, however, necessarily the case in many African states that attempted to build a common national identity on a supra-ethnic/non-ethnic basis but nevertheless failed to do so as the nexus of ethnicity and state power remains firmly entrenched. Here, the claim is not for cultural or political autonomy but access to state power. They would demand the removal of hurdles to access state power, decrying the status quo in which "some ethnic groups will have much better access routes to the state, while other ethnic groups are excluded." 27 The following observation about the Democratic Republic of Congo captures the political sentiments that exist in many of these African states:

"The Congolese do not typically complain about their integration in the nation. What feeds their grievances is the largely shared impression that their fellow Congolese cheat them and favour their kinsmen at the local level, and that they need to rely on similar solidarities to reach their own goals of safety and well-being. This is what the Congolese refer to as tribalism. "28

Federalism, with its emphasis on subnational autonomy, is not necessarily appealing for this group of political contenders. The institutional response that such groups clamour for is a system that ensures representation of the different groups at the national level, thereby, guaranteeing a share of state power. Their major goal is securing a power sharing deal; the focus is primarily on shared rule rather than self-rule.

26. Norman Wayne, Negotiating nationalism: Nation-building, federalism and secession in the multinational state (Oxford: Oxford University Press, 2006), 10.

27. Kymlicka refers to these groups as communal contenders as opposed to ethnonationalists: Kymlicka, "National -building and minority rights: Comparing Africa and the West,"

28. Pierre Englebert "The Democratic Republic of Congo: Fault lines and local fissures," in On the fault line: managing tensions and divisions within societies, Profile eds. Jeffrey Herbst, Terence McNamee and Greg Mills (books: London 2012), 33-45, 36

L'Europe en formation $n^{\circ} 363$ Printemps 2012 - Spring 2012 
Of course, this is not to suggest that subnational autonomy does not placate politically mobilized ethnic groups. Subnational autonomy by definition multiplies access to political and economic power. By providing ethnic groups a region in which they are a majority, it facilitates opportunities for political participation and representation. It provides ethnic/regional elites with the means for political participation and representation in the leadership structures of their respective subnational governments, promoting the self-management of communities. The conspicuous absence of federalism and subnational autonomy on the agenda of many political movements in Africa is thus not necessarily linked to the inability of the system to address the concerns of these political communities. It is rather the nature of the nation-building project that was advanced by many states in Africa that might explain the dampened interest in federalism and territorial autonomy.

\section{A new era of federalism in Africa?}

Although not necessarily the case with most African states, the reality of disgruntled ethnic groups and political violence, spilling over, in many cases, into intractable armed conflicts, has forced the restructuring of the state and, more specifically, the introduction of subnational autonomy on the political agenda of several African states. This is particularly true in states that are characterized by ethnic stratification and hierarchy in which a particular group, as a result of a nation-building project that sought to impose the language and culture of a particular ethnic group over the rest of the population, occupies a unique and relatively privileged position vis-à-vis the rest. Many of these states have faced and continue to face ethnic groups that wage collective action demanding greater autonomy. Many of these African states, albeit begrudgingly, have now adopted constitutions that envisage the transfer of power to smaller subnational units.

In fact, history, it seems, is repeating itself. As one author has put it, "as an idea that was universally rejected in the 1960s through to the early 1990s across Africa", federalism is now, "an idea whose time has come in several countries". ${ }^{29}$ It is those same states that, in the early days of independence, conceded to the inclusion of the federal idea in their constitutions only to quickly abandon it, that are now jumping onto the federalist bandwagon. These states do not necessarily recognize themselves as federal states. In fact, a common feature of African states deciding to introduce subnational autonomy is the reluctance to explicitly recognize that they have adopted some form of federalism. Federalism is regarded as the ' $F$ ' word and it is carefully avoided.

29. Barkan, "Ethnic fractionalization and the propensity for conflict in Uganda, Kenya and Tanzania," 168. 
The use of the term "federalism" to designate the state was a major point of contention in the making of the 1996 South African constitution. The system of government that South Africa has adopted has important elements of federalism. With its three levels, or to use the South African term 'spheres', of government, each with devolved powers and functions exercised and implemented by a directly elected parliament and executive respectively, and a second chamber that brings the provinces into the national decision-making process, ${ }^{30}$ the inclusion of South Africa among the ranks of federations, as contemporary literature on federalism does, should not come as any surprise. Despite this, the South African constitution and the authorities in that country have deliberately avoided the use of the "F" word. Even the new constitution of Kenya is content with describing its political system as one of devolution. This is despite the fact that the constitution provides for the establishment of directly elected subnational units, which enjoy some level of autonomy by exercising assigned powers, and a second chamber that is representative of its subnational units. ${ }^{31}$ Similarly, the 2005 constitution of the Democratic Republic of Congo bears the hallmarks of a federation. It provides for the establishment of 25 autonomous provinces that are independently elected and whose constitutionally assigned powers can only be amended with their consent. More importantly, the provinces, which are brought into the national decision-making process through their representation in the Senate and the Conference of Governors, have the power to retain 40 percent of the tax revenue they generate. ${ }^{32}$ But nowhere in the Constitution would one find the term "federalism".

Generally, the reluctance to use the term federalism can be partly explained by deep misgivings about federalism, more specifically by the tainted image and history of federalism in many of these countries. In Kenya, the debate on federalism, as indicated earlier, can be traced back to the early days of independence when political groups, claiming to represent the smaller ethnic groups in Kenya, agitated for "Majboism". Many Kenyana associate "Majboism" with the division of people along tribal lines and the disintegration of the country. ${ }^{33}$ Opponents turned "majimboism into a slur: [and] majimboists were derided as [antinationalist] tribalists who opposed the broader goals of nationalism". ${ }^{34}$ In South Africa, federalism is associated with the "bantustanisation" of South Africa, a policy of the apartheid government that divided the black population along ethnic lines and sought to expel them from the physical and political terrain of South Africa and

\footnotetext{
30. Constitution of the Republic of South Africa Act 108 of 1996.

31. Constitution of Kenya, 2010

32. Constitution of the Democratic Republic of Congo, 2005

33. Yash Ghai, "Devolution: Restructuring the Kenyan state,"

34. Okoth-Ogendo, "Constitutions without constitutionalism: Reflections on an African political paradox,"

L'Europe en formation $n^{\circ} 363$ Printemps 2012 - Spring 2012
} 
establish white South Africa for white South Africans. The same is true with the DRC. As one author put it, "[c]onstitutionally, the DRC has had an ambivalent relationship with federalism". ${ }^{35}$ The secessionist movements and the civil war that the DRC experienced in the early days of its independence have contributed to the controversial history of federalism in that country.

From the foregoing, the position in Africa, it seems, is that states should worry little about the designation of the state. As the drafters of the South African constitution have done, the focus should be on an appropriate system of constitutional government that provides for "good and effective government" 36 and not on the formal description of the state. In any case, these decisions are attributed to the deep suspicion with which federalism is viewed in many of these African states; a view that regards federalism as a poor device to manage fault lines and a recipe for state disintegration. The only country in Africa, with the exception of Africa's longest run federal experiment, Nigeria, that boldly declares itself as a federal republic, is Ethiopia. The opening article of the 1995 Constitution of Ethiopia declares the establishment of "The Federal Democratic Republic of Ethiopia."

Despite the reluctance to extend a formal recognition, the use of autonomous or semi-autonomous subnational units in a federal or semi-federal frame for managing internal conflicts, forms an important part of the institutional response that several African states have adopted to deal with the challenges of ethnic diversity. This involves providing autonomy in the form of subnational units (referred to as provinces in South Africa and the DRC, states in Nigeria, counties in Kenya and regions in Ethiopia) to a geographically concentrated ethnic group. A prime example of this approach is the Ethiopian federation. The Ethiopian federal experiment, which was launched almost two decades ago, is primarily designed to accommodate the country's ethnic diversity. ${ }^{37}$ This is evident in the territorial organization of the Ethiopian federation. The federation is divided into nine regions that are, by and large, demarcated along linguistic lines. More than two thirds of the people that live in five of the nine regions belong to a single ethnic group. Each of these states is also designated after the name of the dominant ethnic group in each state, marking the explicit construction and designation of each regional state as the homelands of a single ethno-linguistic group. With the view to accommodate its 250 ethnic groups, Nigeria has also employed the 'territorial autonomy solution'. Borrowing the words of Elaigwu, "over the years, states and local governments were created as a means of minimizing the majority-minority

\footnotetext{
35. See Thomas Turner, "Congo-Kinshasa leans towards federalism," Federations Magazine vol. 7(1) (2007). 36. C. Murray, "Republic of South Africa," in Legislative, executive and judicial governance in federal countries: Global dialogues on federalism, ed. K. Le Roy and C. Saunders (Montreal and Kingston: McGill-Queens University Press, Vol. 3, 2006), 259-288, 263.

37. For more see: Yonatan Fessha, Ethnic diversity and federalism: Constitution making in South Africa and Ethiopia (Surrey: Ashgate. 2010).
} 
conflicts" ${ }^{38}$ During negotiations in the 1990 s for a democratic South Africa, both conservative Afrikaners and Zulu nationalists pressed for a federal structure in the hope that they would gain control of some of the provinces. South Africa's 1996 Constitution, with its federal arrangement and nine provinces, has made important, albeit implicit, concessions to this objective. The same goes for the quasi-federal constitution of the Democratic Republic of the Congo. The increase of the number of provinces from eleven to twenty-five is designed to increase the "opportunities for the local management of fault lines". ${ }^{39}$ Kenya's new constitution provides for a devolved system of government that is based on the establishment of forty-seven county level governments. ${ }^{40}$

The lesson from African experience has been that when a state fails to readily acknowledge and accommodate its ethnic diversity, through federalism or other such arrangements, this generally leads to increased tensions among ethnic groups. Failure to address the concerns of such communities can also lead to a devastating result for the territorial integrity of the state. The case of Sudan illustrates this very well where a failure to accommodate the claims of disgruntled communities eventually resulted in border changes. But the mere adoption of federal or similar arrangements does not signify an effective accommodation to ethnic diversity. The success of subnational autonomy arrangements in addressing ethnic divisions is not guaranteed. Success depends, among other things, on the particular nature of the federal design. The question is then whether the federal design that African states have adopted is appropriate to deal with the exigencies of ethnic diversity.

At the centre of this debate is the territorial definition of federal subunits, one of the important issues that have emerged with the reintroduction of federalism in Africa. The focus is on how the territorial design of the federation can be used to regulate the challenges of ethnic diversity. More specifically, the question is to what extent subnational units should ethnically be defined. This is an important variable in designing a federal solution that helps to respond to the challenges of ethnic diversity while at the same time avoiding the danger of further entrenching and deepening those same divisions.

\section{The territorial definition of federal sub-units}

In Africa, one federation that has explicitly defined its subnational units in terms of ethnicity is Ethiopia. Ethnicity is the basis for the organization of the

\footnotetext{
38. J. Iswa Elaigwu, "Nigeria: The decentralization debate in Nigeria's federation," in The Federal idea: Essays in honour of Ronald L. Watts, ed. Thomas J. Courchene, John R. Allan, Christian Leuprecht and Nadia Verrelli (Institute of Intergovernmental Relations: Kingston, Ontario, 2011), 429-444, 440.

39. Pierre Englebert "The Democratic Republic of Congo: Fault lines and local fissures," 43

40. The Constitution of Kenya, 2010
}

L'Europe en formation $n^{\circ} 363$ Printemps 2012 - Spring 2012 
Ethiopian federation. The use of ethnic based territorial autonomy to address ethnic divisions in that country has had a mixed report card. The federal experiment has contributed to the extended participation of minorities in the political system. Notwithstanding the claim about "true representation or authentic representatives" and the dominance of a single party, the system has turned "obscure districts" into important units of government with significant local empowerment. ${ }^{41}$ In contrast to the selective cooptation of the previous regimes, the federal government has also become more diversified than ever in terms of ethnic composition as all subnational administrations are occupied by locals.

The constitutional decision to provide a mother state to each ethnic group and to do so by making ethnic groups dominant in a regional state is not, however, without its problems. In as much as the federal response has facilitated the recognition of ethnic diversity and responded to ethnic claims, it has elevated ethnic identity to a primary political identity. This has, in turn, facilitated identity fragmentation along ethno-linguistic lines. ${ }^{42}$ This has been observed, for example, in the proliferation of ethnic-based parties or movements. Although one may be tempted to dismiss the proliferation of ethnic-based parties as the work of the ruling party, there is enough evidence to show that the opposition is also fragmented along ethnic lines. Related to the proliferation of ethnic-based parties is the translation of cultural communities into political communities. Ethnic identities that, in the past, had a mere cultural status are increasingly turning into politically relevant entities. This is evident, among other things, in the relentless demand for recognition, autonomy and representation by many ethnic groups, which is especially visible in some of the ethnically plural regional states where ethnic groups of all sizes have demanded some form of recognition and territorial autonomy. ${ }^{43}$ The tendency of fragmentation in other socio-economic institutions along ethnic lines cannot be easily discounted either.

The unremitting demands of ethnic groups of all sizes to be incorporated or transferred into one or another regional unit is another indication of the fragmentation of the population along ethno-linguistic lines. Many small ethnic groups that have been demarcated into one region have demanded to be incorporated into another. Of course, there is nothing unusual in communities demanding transfers from one regional state to another. The phenomenon of communities demanding or even refusing transfers to another subnational unit is not unique to Ethiopia. Very recently, residents of some communities in South Africa, for example, protested the government's decisions to transfer their municipalities to

41. Feyissa Dereje, “The experience of Gambella Regional state," in Ethnic federalism: The Ethiopian experience in comparative perspective, ed. D. Turton (Athens: Ohio University Press 2006), 208-230.

42. Fessha, Ethnic diversity and federalism: Constitution making in South Africa and Ethiopia.

43. See S. Vaughan, "Responses to ethnic federalism in Ethiopias southern region," in Ethnic federalism: The Ethiopian experience in comparative experience ed. D. Turton (Athens: Ohio University Press, 2006) 181-207. 
other provinces. ${ }^{44}$ The difference lies in the reasons behind these demands and protests. In South Africa, residents of the Matatiele community protested their incorporation into the Eastern Cape from KwaZulu-Natal because of the perception that KwaZulu-Natal offers better services than the Eastern Cape. In contrast, the demand of communities in Ethiopia to be transferred to one or another regional state is not motivated by concerns related to service delivery but by issues of identity and belongingness. Members of some communities do not feel that they belong to the regional state they have been demarcated into. This is another consequence of the geographical logic of the federation, which is inherent in the decision of the Constitution to explicitly construct and designate regional states as belonging to particular ethnic groups, leaving the rest with a feeling of being outsiders.

The Ethiopian experience seems to suggest that the same approach towards the territorial definition of subnational units that provides ethnic groups with self-management has the potential to strain inter-ethnic relations by reifying the political dimension of ethnic identity. It particularly invokes the question whether the imperatives of accommodating ethnic diversity requires the state to demarcate each, or at least the major, ethnic group into one subnational unit. Africa's longest running federal experiment, Nigeria, seems to provide a different alternative in terms of the territorial definition of federal subnational units.

As indicated earlier, the Nigerian federation was initially structured along the fault lines of the three major ethnic groups. Confronted with the problem of providing a mother state to each large ethnic group, Nigeria has continuously adjusted its internal boundaries. Initially, the original geographical configuration of the federation was abandoned and replaced with twelve state structures in 1967. Since then the number of states has increased continuously. Currently, the number of states in Nigeria stands at 36. An important component of this transformation is that the repeated readjustment of the federation from three to the present 36 states involved the use of "the federal structure to fragment, cross-cut and sublimate the identities of each of the [three] major ethnic groups". 45 The continuous adjustment of internal boundaries brought about and buttressed historic intra-ethnic divides within each of the three large ethnic groups. Although the reconfiguration has not totally taken away the use of ethnicity as a basis for political mobilization in the pursuit of power and resources, it has, by demarcating each large ethnic group into a number of states, created intra-ethnic mobilization and competition. As a result, "there have been conflicts between otherwise ethnically homogenous major sub-ethnic states over the sharing of the assets of subdivided regional or state units, over revenue allocation and over the employment in state-level

44. Yonatan T. Fessha "SA's mazy route through the province of ethnicity," Business Day: (12-06-2007).

45. Suberu, "Attractions and contradictions of ethnic federalism: The Nigerian experience,"

L'Europe en formation $n^{\circ} 363$ Printemps 2012 - Spring 2012 
bureaucracies of so-called 'non-indigenes'-that is Nigerian resident in states other than their own". 46

The new constitution of Kenya seems to follow a similar approach. The boundaries of the 47 counties, more or less, mimic the colonial districts that were, to a large extent, demarcated along ethnic lines. By way of emphasizing the ethnic basis of the counties, one author laments that "[t]he suggested 47 counties are not much different from the Masai country [and] Akamba country design under the colonial administration." 47 The territorial arrangement does not, however, demarcate each large ethnic group into one specific county. ${ }^{48}$ It rather divides numerically large ethnic group into a number of counties. Smaller ethnic communities, on the other hand, are given autonomy and greater political voice as they control counties in which they are in a majority.

South Africa has accommodated ethnic diversity without even making ethnicity an explicit basis for the organization of the state. South Africa's nine provinces, although not explicitly, contribute to the management of ethnic diversity. This partly has to do with the fact that the majority of the ethnic groups in South Africa have a province in which they are in the majority. ${ }^{49} \mathrm{~A}$ clear concentration of particular ethnic groups in the majority of these provinces means that most ethnic communities are provided with the means for political participation and representation in the leadership structure of their respective provinces. The fact that the Constitution allows each province to choose its official language(s) further facilitates the management of its own affairs by the provincially dominant ethnic groups. The decision to accommodate ethnic diversity without explicitly articulating the definition of the territorial units in ethnic terms seems to have helped the country avoid conditions that make ethnicity a single rallying point of political competition and cooperation.

The foregoing attests to the widely established thesis that emphasizes the interplay between institutional design and political behaviour; that the institutional structure of the state and, more specifically, in our case, the territorial design of the state, goes a long way in determining the salient identities that become a basis for political mobilization. The experience of African federations suggest

\footnotetext{
46. Rotimi T. Suberu,, "Nigeria," in Diversity and unity in federal countries: Global dialogue on federalism Vol. 7 eds. Luis Moreno and Cesar Colino (Montreal and Kingston: McGill-Queens University Press, 2010), $227-$ 258. 233.

Suberu attributes the success of the Nigerian federation in avoiding large scale ethnic conflicts, that engulfed the federation in its early years, to the transformation of Nigeria "from a federation of three major ethnic regions to a union of multiple, smaller constituent units," (Suberu, "Attractions and contradictions of ethnic federalism: The Nigerian experience," 228).

47. O. Steve Akoth, "Challenges of nationhood: identities, citizenship and belonging under Kenya's new constitution," Society for International Development (SID) Constitution Working Paper (2011): 15.

48. Barkan, "Ethnic fractionalization and the propensity for conflict in Uganda, Kenya and Tanzania," 169.

49. Fessha, Ethnic diversity and federalism: Constitution making in South Africa and Ethiopia, 113.
} 
that demarcating each large ethnic group into one specific subnational unit can radicalize ethnic allegiance, contribute to the ethnicisation of the system, cause continuous tension and place a strain on inter-ethnic relations. On the other hand, dividing numerically large ethnic groups into a number of constituent units without denying them territorial autonomy might have the consequence of promoting competitive or cooperative relations that do not reproduce a country's ethnic fault lines. ${ }^{50}$ In other words, it might contribute to the development of "a more 'civil' and 'gentle' politics" as opposed to the emotionally charged ethnic politics that can often spiral into violent confrontation. ${ }^{51}$

\section{Minorities within minorities}

In as much as territorial autonomy, defined in exclusive ethnic terms or otherwise, provides an opportunity to locally manage fault lines, it is not a panacea to the multi-ethnic challenge. As the experience of Ethiopia and Nigeria illustrates, the territorial structure of federalism might help to avoid large scale ethnic conflicts but the practical impossibility of creating an ethnically pure subnational unit brings new tension: the majority-minority tension at the level of the constituent units. This is the case, for example, in Ethiopia where the ethnic groups that are numerically dominant at the subnational level consider themselves "owners" of their respective subnational units. People that do not belong to the regionally empowered group "have practically no rights or political voice". ${ }^{52}$ This is despite the fact that these individuals account for a significant segment of the regional population. For example, in one of the regions, the number of such individuals reaches close to three million. ${ }^{53}$

The Nigerian federation is also strained by a similar challenge. The attempt to accommodate ethnic diversity through territorial autonomy in the form of subnational units has "created new majorities and new minorities at the subnational level' in the form of indigenes and non-indigenes. Discrimination against "nonindigenes" is commonplace in almost all states of Nigeria. ${ }^{54}$ Despite the provision of the Constitution that protects the rights of every Nigerian "to settle down anywhere in the country to pursue their legitimate businesses and [enjoy] equal rights everywhere", Elaigwu notes, "[m]any states and communities recognize their indigenous

50. Suberu, "Attractions and contradictions of ethnic federalism: The Nigerian experience,"

51. Barkan, "Ethnic fractionalization and the propensity for conflict in Uganda, Kenya and Tanzania," 168.

52. Assefa Fiseha and Mohammed Habib, "Ethiopia," in a global dialogue on federalism, VII. eds Moreno and Collino, 2010.

Suberu, "Nigeria,"139-167, 154.

53. Conflicts between regionally empowered group and internal minorities have led to devastating resulting, including the loss of life and destruction of property, see: Assefa and Mohammed, "Ethiopia," in a global dialogue on federalism, 2010.

54. Suberu, "Nigeria," 235.

L'Europe en formation $n^{\circ} 363$ Printemps 2012 - Spring 2012 
groups and can easily isolate settlers, and treat them as such, no matter how long they have lived in the area" ${ }^{55}$ As is the case in Ethiopia, discrimination against nonindigenes has created a sense of exclusion amongst the latter, relegating millions of individuals to second-class citizens in their own country. ${ }^{56}$

In both Ethiopia and Nigeria, the exclusionary policies of subnational units seem to have their root in federal policies and laws that make belonging to an ethnic group or, as in the case of Nigeria, being an indigene to a subnational unit, an important political consideration. The Ethiopian Constitution, as indicated earlier, designates most of the regions as belonging to a specific ethnic group, creating the feeling of ownership amongst individuals that belong to the regionally dominant group and a sense of exclusion amongst those that have ostensibly originated from other parts of the country (i.e. internal migrants). Similarly, the Nigerian Constitution, based on its constitutional principle of "the federal character", uses the criteria of "indigeness" in providing representation in the institutions of the federal government.

The experiences of the two federations suggest that a federal arrangement that does not accommodate those who do not belong to the empowered regional majority is likely to be subjected to perennial stress and is less likely to succeed in managing ethnic diversity. This particular experience of African federations also highlights one of the conditions that continue to threaten the federal experiment in Africa, namely the lack of consensus on liberal democratic values. One of the reasons for the success of federations in the west is the widespread consensus on liberal democratic values. As Kymlicka notes, most western federations are not afraid that national minorities will use their power to "persecute, dispossess, expel or kill anyone who does not belong to the minority group". ${ }^{57}$ In the absence of consensus and respect for liberal democratic values, the precarious federal experiments in Africa will continue to pose a grave threat to the fundamental rights of individuals and to the political stability of the state.

The imperatives of developing consensus and respect for liberal democratic values becomes more evident when one notes that the territorial approach to subnational autonomy may not necessarily respond to the concerns of all ethnic groups. This basically relates to the fact that the territorial concentration of ethnic groups is a precondition for the extension of subnational autonomy towards a particular group. To a group that is not geographically concentrated, the territorial solution that federalism provides is less appealing. The territorial arrangement in South Africa that, albeit indirectly, gives ethnic groups political space at the subnational level, does not cater for Afrikaners who are dispersed throughout the

55. Elaigwu, "Nigeria: The decentralization debate in Nigeria’s federation," 440.

56. Suberu, "Nigeria," 235

57. Kymlicka, "National-building and minority rights: Comparing Africa and the West,"

L'Europe en formation $n^{\circ} 363$ Printemps 2012 - Spring 2012 
country. This would require the state to look for innovative ways of addressing the anxieties of groups that cannot benefit from a territorial solution. However, at a minimum, it requires strict enforcement of liberal values in the form of fundamental individual rights.

\section{The question of secession}

Although the provision of territorial autonomy has gone a long way in managing the challenges of ethnic diversity and preventing large scale ethnic conflicts, a clamour for secession continues to exist in some of these federations. This is especially true in Ethiopia and Nigeria although the DRC is also not immune to secessionist outbursts. In Ethiopia, the Oromo Liberation Front (OLF), a liberation movement that claims to represent the Oromo (largest ethnic group in Ethiopia), continues to engage in armed movement having the establishment of an independent state for the Oromo as its major objective. The Ogaden National Liberation Front (ONLF) is another armed organization that fights to secure the establishment of a separate country for the Somali ethnic community, the third largest ethnic group in Ethiopia. In Nigeria, political movements that have created secessionist projects include the Movement for the Actualization of the Sovereign State of Biafra (MASSOB) ${ }^{58}$ The aim of this largely peaceful (non-militant) movement is to revive and actualize the attempted secession of the predominantly Ibo state of Biafra between 1967-70. Secessionist sentiments are also evident in the militant MEND, the Movement for the Emancipation of the Niger Delta, which espouses, albeit in a less official manner, the "creation of an independent Ijaw nation-state". Now and then, the partition of the DRC is also touted as an option for the achievement of a meaningful peace in that country. Very recently, the government of the DRC has reported that it has foiled a secession plot by the mineral-rich Katanga province, ${ }^{59}$ the same province that attempted to secede from the DRC in the 1960s before it was crushed in a bloody civil war.

As argued elsewhere, there is no guarantee that secession will help to achieve the desired objective of peace and security. Secession might be regarded as a viable means of managing ethnic conflicts when the partition results in two ethnically macrocosmic states. Given the impractical reality of creating political boundaries that neatly match ethnic boundaries, changes in boundaries, through partition, might only transfer the locus of ethnic conflicts and might even give rise to new ethnic conflicts. As the experience of the newly born South Sudan indicates, there is no guarantee that partition will not "activate and energize new fault lines" ${ }^{60}$

\footnotetext{
58. Suberu, "Nigeria,"

59. IRIN 2012, DRC: Secession plot failed, government official says available at <http://www.irinnews.orgprintreport.aspx?reportid=54392> accessed on 27 February 2012

60. Rader, "Overcoming the past: War and peace in Sudan and south Sudan," 45

L'Europe en formation $n^{\circ} 363$ Printemps 2012 - Spring 2012
} 
Secession might also create micro-states that are too small to be regarded as states that are economically viable. Add to this the prescription of secession as an institutional solution which might "give rise to [a] protracted border crisis in countries like Nigeria, which alone contains more than 250 ethnic groups" ${ }^{61}$ Although it has not prevented the secession and creation of new states like South Sudan and Eritrea, the Organisation of African Unity's principle of upholding colonial boundaries also means that the creation of new states through secession is not an option that receives recognition easily. A case in point is the African Union's snub of Somaliland's quest for formal recognition of its independence after it severed its ties from what was once the Somali Democratic Republic (with which it was voluntarily united in 1966) and established a promising move towards democracy and rule of law.

It is also important to note that Ethiopia's constitution is the only one on the continent that explicitly recognizes the right to secession. Article 39 of the Constitution provides each ethnic group the right to secede from a federation provided that it has shown a proven support as required by the Constitution. Certainly, as indicated above, enshrining in a constitution the right of a constituent unit to secede is fraught with pitfalls. But it must also be acknowledged that sometimes there may not be much choice if instability or even civil war is to be avoided. In Ethiopia, the political forces at play during the transition from military rule to a federal arrangement would not have settled for anything less than entrenching the right of secession in the constitution. Not acceding to that demand could well have jeopardized a peaceful transition. ${ }^{62}$

\section{Conclusion}

The history of federalism in Africa is a history of ambivalence. In the run up to independence, numerically small ethnic groups and those with historical distinctiveness saw federalism as a bulwark against the domination of large groups or the loss of privileged status. It was an idea that galvanized many political movements that, following the retreat of colonial powers, emerged to represent the interest of these small and historically distinctive ethnic groups. But it was also an idea that was subsequently rejected by those that wield state power and thrown into historical dustbins. In the last decade or so, however, we have witnessed the rise of federalism from the dustbin of African political history.

The increased and renewed interest in federal arrangements that Africa has experienced in the last two decades or so, provides for a new opportunity to

61. Fessha, Ethnic diversity and federalism: Constitution making in South Africa and Ethiopia, 113.

62. Alem Habtu, "Multi-ethnic federalism in Ethiopia: A study of the secession clause in the Constitution," in Publius: The Journal of Federalism 35(2) (2005): 313-337. 
engage in innovative federal experiments that could go a long way in addressing the concerns of disgruntled ethnic communities. This article has shown that African states should worry about the territorial definition of subnational units. The same approach of territorial autonomy that helps to manage ethnic fault lines might further entrench and exacerbate those same societal divisions it is designed to manage. The experience of African federations, particularly Nigeria and South Africa, suggest that states can respond to the challenges of ethnic diversity without institutionalizing ethnic divisions. But equally important to the territorial design is the political commitment to the rule of law and fundamental human rights. The first is crucial in ensuring the realization of the promises of federalism while the second helps to avoid political instability and promote social cohesion. If constitutional rules are breached at will and the fundamental rights of individuals that belong to minorities are violated with impunity, the federal experiment is less likely to succeed.

Finally, the process that leads to the launching of a federal experiment is also crucial in the success of a federation. One of the major challenges of the Ethiopian federal experiment is legitimacy as the centralists continue to paint the experiment as a recipe for disintegration. This perhaps has to do with the fact that there is nothing in the federal design that represents a concession to the demands of those that were concerned about the threat to national unity. The federal design "does not provide equal recognition to the competing centripetal and centrifugal forces whose struggle for a place in the public spheres continues to define the political realities of the Ethiopian state and society". ${ }^{63}$ This, in fact, is what distinguishes the Ethiopian system from the South African institutional response, which is the outcome of a negotiated outcome. The negotiated nature of the South African constitution has led stakeholders and politicians alike to consider the constitution, not only as "basic law, or a higher law," but "our law". The final outcome provides sufficient recognition to the competing centripetal and centrifugal forces that, at the moment of constitution-making, represented the opposing political formations. Process is, therefore, equally important in ensuring that the federal design that a country chooses mirrors its political realities and is therefore acceptable by the major contenders of power.

\footnotetext{
Abstract

The history of federalism in Africa is a history of ambivalence. In the run up to independence, federalism was an idea that galvanized several political movements that, following the retreat of colonial powers, emerged to represent the interest of ethnic groups that were anxious about their political status in post colonial Africa. But it was also an idea that was subsequently rejected by those that wield state power and thrown into historical dustbins. Recent developments indicate that the federal idea that was never given a chance to develop and was being strangled at birth is now re-entering the constitutional scene of several African countries. This short article examines how African federations have responded to the ethnic di-
}

63. Fessha, Ethnic diversity and federalism: Constitution making in South Africa and Ethiopia.

L'Europe en formation $n^{\circ} 363$ Printemps 2012 - Spring 2012 
versity that characterizes their societies. In particular, it examines how the territorial autonomy solution, implicit in these federations, have helped to deal with the challenges of ethnic diversity.

\section{Résumé}

L'histoire du fédéralisme en Afrique est une histoire d'ambivalence. Dans la course à l'indépendance, le fédéralisme fut une idée qui galvanisa de nombreux mouvements politiques qui, après le retrait des autorités coloniales, étaient apparus pour représenter les intérêts des groupes ethniques inquiets de leur statut politique dans l'Afrique postcoloniale. Cependant, ce fut également une idée ensuite rejetée par tous ceux qui exercèrent le pouvoir étatique, qui la jetèrent dans les poubelles de l'histoire. Les évolutions récentes indiquent l'idée fédérale, à qui l'on n'avait jamais laissé une chance de se développer et qui fut étranglée dès la naissance, revient aujourd'hui sur la scène constitutionnelle de plusieurs pays africains. Cet article étudie comment les fédérations africaines ont répondu à la diversité ethnique qui caractérise leurs sociétés. Il s'intéresse tout particulièrement à savoir comment la solution d'une autonomie territoriale, implicite dans ces fédérations, a aidé à gérer les défis de la diversité ethnique. 